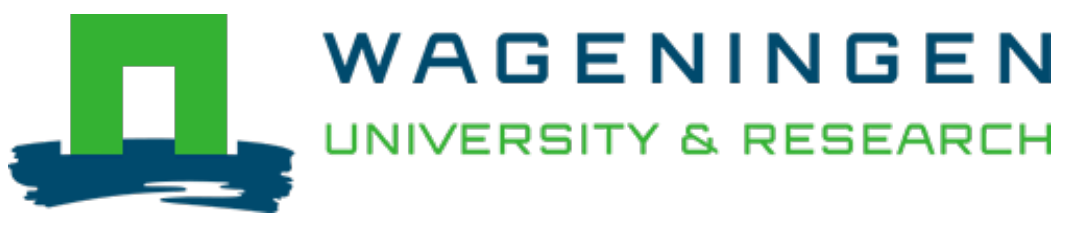

\title{
Consumer liking, purchase intent, and willingness to pay for Lupinus mutabilis Sweet in relation to debittering treatments
}

\author{
Food Quality and Preference \\ Carvajal-Larenas, F.E.; Koziol, M.; Linnemann, A.R.; Nout, M.J.R.; Boekel, M.A.J.S. \\ https://doi.org/10.1016/j.foodqual.2014.10.006
}

This publication is made publicly available in the institutional repository of Wageningen University and Research, under the terms of article $25 \mathrm{fa}$ of the Dutch Copyright Act, also known as the Amendment Taverne. This has been done with explicit consent by the author.

Article 25 fa states that the author of a short scientific work funded either wholly or partially by Dutch public funds is entitled to make that work publicly available for no consideration following a reasonable period of time after the work was first published, provided that clear reference is made to the source of the first publication of the work.

This publication is distributed under The Association of Universities in the Netherlands (VSNU) 'Article $25 \mathrm{fa}$ implementation' project. In this project research outputs of researchers employed by Dutch Universities that comply with the legal requirements of Article $25 \mathrm{fa}$ of the Dutch Copyright Act are distributed online and free of cost or other barriers in institutional repositories. Research outputs are distributed six months after their first online publication in the original published version and with proper attribution to the source of the original publication.

You are permitted to download and use the publication for personal purposes. All rights remain with the author(s) and / or copyright owner(s) of this work. Any use of the publication or parts of it other than authorised under article $25 \mathrm{fa}$ of the Dutch Copyright act is prohibited. Wageningen University \& Research and the author(s) of this publication shall not be held responsible or liable for any damages resulting from your (re)use of this publication.

For questions regarding the public availability of this publication please contact openscience.library@wur.nl 


\title{
Consumer liking, purchase intent, and willingness to pay for Lupinus mutabilis Sweet in relation to debittering treatments
}

\author{
F.E. Carvajal-Larenas ${ }^{\text {a,b,c,1 }}$, M. Koziol ${ }^{\text {a,1 }}$, A.R. Linnemann ${ }^{\text {b,* }}$, M.J.R. Nout ${ }^{\mathrm{c}, 2}$, M.A.J.S. van Boekel $^{\text {b,3 }}$ \\ ${ }^{a}$ Estudios de Economía Industrial, Gerencia de Operaciones y Proyectos de Inversión, Colegio Politécnico, Universidad San Francisco de Quito, Círculo de Cumbayá, P.O. \\ Box 17-12-841, Quito, Ecuador \\ ${ }^{\mathrm{b}}$ Food Quality and Design, Wageningen University, P.O. Box 17, 6700AA Wageningen, The Netherlands \\ ${ }^{\mathrm{c}}$ Laboratory of Food Microbiology, Wageningen University, P.O. Box 17, 6700AA Wageningen, The Netherlands
}

\section{A R T I C L E I N F O}

\section{Article history:}

Received 15 November 2013

Received in revised form 22 October 2014

Accepted 27 October 2014

Available online 4 November 2014

\section{Keywords:}

Lupin

Consumer preference

Process optimization

Price

Modeling

\begin{abstract}
A B S T R A C T
Interrelationships between food processing conditions, consumer liking, purchase intent and willingness to pay can be studied and modeled as exemplified by this paper on lupin (Lupinus mutabilis). Lupin was debittered by 12 different aqueous treatments and evaluated by 99 consumers. First they scored the products on the basis of liking. Next, they were informed about the price of the products and asked to rank their purchase intent in relation to their liking scores and product price. Treatments with more processing (i.e. longer agitation times and/or more frequent changes of water) increased the product price but diminished liking. Consumers did not choose between liking and price; the purchase intent was the combined effect of both variables. Willingness to pay was inferred from the purchase intent plot. For example, at a purchase intent of 2, consumers would accept an increase in price of $0.3 \$ / \mathrm{kg}$ if liking increased from "like slightly" to "like moderately". In the studied range, the effect of processing on liking and expected price, as well as their effect on purchase intent, could be described by first order regression equations.
\end{abstract}

(c) 2014 Elsevier Ltd. All rights reserved.

\section{Introduction}

Lupins (Lupinus spp.) are legumes used principally as a protein source in human and animal nutrition (Güémes-Vera, PeñaBautista, Jiménez-Martínez, Dávila-Ortiz, \& Calderón-Domínguez, 2008). The FAO (2012) reports that in 2010 a quantity of 934,426 metric tons of lupin were produced in Europe (primarily in Germany, Poland, the Russian Federation and Mediterranean countries), Australia, South Africa, and South America. Four major species of lupins are cultivated, namely Lupinus albus, Lupinus luteus, Lupinus angustifolius and Lupinus mutabilis, of which the latter has the highest average protein and fat contents, namely $44 \%$ and $18 \%$ on a dry weight basis, respectively (Pate, Williams, \& Farrington, 1985), comparable in quantity and quality to what is present in soya bean (Gueguen \& Cerletti, 1994; Santos, Ferreira, \& Teixeira, 1997). Whole lupin seeds are consumed as a snack or

\footnotetext{
* Corresponding author. Tel.: +31317 483668.

E-mail addresses: fcarvajal@usfq.edu.ec (F.E. Carvajal-Larenas),mkoziol@usfa edu.ec (M. Koziol), anita.linnemann@wur.nl (A.R. Linnemann), rob.nout@wur.n (M.J.R. Nout), tiny.vanboekel@wur.nl (M.A.J.S. van Boekel).

1 Tel.: +5932 2971867; fax: +59322890070

2 Tel.: +31317 482887

3 Tel: +31317484281
}

as an ingredient in fresh salads and soups (Villacrés, Peralta, \& Alvarez, 2003).

Lupin contains about 70 different alkaloids, which are toxic (Aguilera \& Trier, 1978; Australia New Zealand Food Authority, 2001; Camacho et al., 1991; Jiménez-Martínez, HernándezSánchez, \& Dávila-Ortiz, 2003), especially the sparteine and lupanine types (Jiménez-Martínez et al., 2003), and thus these must be removed prior to consumption. Several researchers have attempted to improve the debittering of the seed because the current processes use much water and time, or produce chemical waste, or extract only a limited amount of alkaloids (CarvajalLarenas, van Boekel, Nout, Linnemann, \& Koziol, 2013). Most published studies on debittering include a soaking stage of the seed in water, up to $18 \mathrm{~h}$ (Jiménez-Martínez, Hernández-Sánchez, \& Dávila-Ortíz, 2007) or 20 h (Villacrés, Caicedo, \& Peralta, 2000), followed by cooking for $0.5 \mathrm{~h}$ (Villacrés et al., 2000) to $6 \mathrm{~h}$ (Jiménez-Martínez et al., 2003). After soaking and cooking, the alkaloids can be removed by biological (Agosin, Diaz, Aravena, \& Yañez, 1989; Dagnia, Petterson, Bell, \& Flanagan, 1992; JiménezMartínez et al., 2007; Santana \& Empis, 2001), chemical (Aguilera, Gerngross, \& Lusas, 1983; Jiménez-Martínez et al., 2003; Nossak, Vilegas, Von Baer, \& Lanças, 2000; Ortiz \& Mukherjee, 1982; Torres-Tello, Nagata, \& Dreifuss-Spiegel, 1980) 
or aqueous extraction processes (Caicedo, Peralta, Villacrés, \& Rivera, 2001; Torres-Tello et al., 1980; Villacrés et al., 2000). An aqueous extraction process is advantageous because it avoids the production of chemical waste (Rossetto, 1989) and can be applied to lupin seeds with high alkaloid contents (up to 4.2\%) (Torres-Tello et al., 1980; Villacrés et al., 2000). Moreover, the aqueous extraction process is the only one practised on a household and commercial scale. In the current aqueous extraction process for debittering lupin, the water is refreshed three times per day and is not agitated (Torres-Tello et al., 1980; Villacrés et al., 2000). After washing, the product may contain Escherichia coli and high counts of aerobic bacteria $\left(10^{8} \mathrm{cfu} / \mathrm{g}\right)$. Therefore, it still requires a thermal treatment (boiling for $10 \mathrm{~min}$ ) to render it safe for consumption (Torres-Tello et al., 1980; Villacrés et al., 2000). Finally, the debittered seeds are packed for retailing (Caicedo et al., 2001; Villacrés et al., 2003).

The processing conditions of lupin can affect its sensory properties, and therefore affect the liking for that product (Frewer, Howard, Hedderley, \& Shepherd, 1997). The processing conditions also influence the yield of final product obtained, and the energy, materials, labour and time used. This in turn affects the processing cost and thus the price of the final product (Ghasemlou, Gharibzahedi, \& Emam-Djomeh, 2013). On the other hand, the consumers' purchase intent is not only influenced by sensory characteristics (liking) but also by other characteristics (Holmquist, McCluskey, \& Ross, 2011) such as origin (Stefani, Romano, \& Cavicchi, 2006), reputation, agronomical characteristics, variety and price of the product (Zhang, Gallardo, McCluskey, \& Kupferman, 2010). In addition, it is generally believed that customers are willing to pay higher prices for a more satisfying product (Anderson, 1996). This notion is based on the economic concept of equity theory, which focuses on social exchange (Oliver \& Swan, 1989a, 1989b). When consumers are more satisfied, they feel that they should reciprocate with a high outcome of the exchange and therefore they are willing to pay more for this product than when satisfaction is low (Bolton \& Lemon, 1999). Then, willingness to pay is a measure of the perceived value of a product by consumers expressed in monetary units and in order to establish a fair exchange or to maintain payment equity (Homburg, Koschate, \& Hoyer, 2005). Despite the importance of this relationship, it is not adequately studied. In fact, most studies express this relation just qualitatively or based on anecdotal experience (Homburg et al., 2005). Finally, it is worth to clarify that purchase intent and willingness to pay are both consequences (outputs) of the value assigned by consumers to different characteristics of a product (inputs). The difference is that purchase intent ranks purchase preference (Liu, Kow, Grewal, \& FitzGerald, 2006) of different products based on perceived value, while willingness to pay measures that assigned value in monetary units (Homburg et al., 2005; Stefani et al., 2006). Therefore it is important to understand the relationship between these factors. The generated information can help all actors in a food production chain (from product developers, production managers, financial executives to marketers) to design and choose the appropriate product, for a specific market, in the early stages (Frewer et al., 1997).

In this study, we developed an approach to study and evaluate the interrelationships between food processing conditions, consumer liking, purchase intent and willingness to pay based on the case of debittering lupin. One variety (L. mutabilis Sweet) and one origin of the seed (Ecuador) were used. Characteristics addressing the consumers' purchase intent (P.I.) and willingness to pay (W.T.P.) were narrowed down to product price. In short, the methodology to be developed should give us insight in the influence of: (i) Processing conditions (number of changes of water/day and hours of agitation/day) on sensory characteristics (liking), (ii) Processing conditions on product price, (iii) liking and price on P.I. and W.T.P., and offer the possibility to analyse the findings with regression equations to be used for optimization purposes.

\section{Materials and methods}

\section{Raw lupin}

A batch of raw bitter L. mutabilis Sweet $(150 \mathrm{~kg}$, alkaloid content $2.65 \% \pm 0.02 \%$ d.w.) was obtained by pooling samples of $15 \mathrm{~kg}$ from 10 processors selected at random from the village of San Pedro, Cotopaxi Province, Ecuador. All processors were using the same variety of raw lupin. After mixing, the lupin was put in jute bags and stored at $16{ }^{\circ} \mathrm{C}$ and $80 \%$ Relative Humidity.

\section{Soaking and cooking conditions}

Soaking and cooking processes were carried out as optimized previously (Carvajal-Larenas et al., 2013). Soaking in tap water was for $18 \mathrm{~h}$ at room temperature $\left(18^{\circ} \mathrm{C}\right)$. The initial weight ratio of water:raw seeds (d.w.) was 3:1. More water was added if required to ensure that the seeds always remained under water; this additional water was recorded.

Cooking was carried out for $1 \mathrm{~h}$ at $91.9^{\circ} \mathrm{C}$, corresponding to the boiling point of water in Cumbayá, Quito, Ecuador (altitude $2433 \mathrm{~m}$ ). Petroleum gas was used as fuel. Soaked seeds were added to the boiling water, and cooking time was recorded from the moment that the lupin came in contact with the boiling water. The initial weight ratio of cooking water:soaked seeds was 3:1.

During the experiment the labour (h), water $(\mathrm{kg})$ and seed weight $(\mathrm{kg})$, as well as the consumed amount of petroleum gas $(\mathrm{kg})$ were recorded (weighing scale ES 200L, Ohaus Corporation, NJ, U.S.A.).

\section{Washing conditions}

Twelve experiments were conducted to determine the effect of the amount of washing water and agitation conditions on alkaloid removal, liking, price and willingness to pay. The tested conditions included the number of times the water was changed per day $(2,3$, 6 , and 9 times), and the duration of hydro-agitation per day $(0,11$, and $22 \mathrm{~h}$ ). These were tested in 12 combinations as shown in Table 1. After soaking and cooking, $20 \mathrm{~kg}$ of lupin were put in two plastic net bags ( $10 \mathrm{~kg}$ per each). The bags were put in a stainless steel tank of $0.6 \mathrm{~m}$ length, $0.45 \mathrm{~m}$ width and $0.40 \mathrm{~m}$ depth. Then, $33 \mathrm{~kg}$ of water at $14-16^{\circ} \mathrm{C}$ were added to the tank, which was situated in an environmental chamber $\left(14-16{ }^{\circ} \mathrm{C}\right)$. Next, a hydro-agitation system was activated and the washing process started (Carvajal-Larenas et al., 2013). The system re-circulated water 60 times $\mathrm{h}^{-1}$ and injected water at $50 \mathrm{kPa}$ into the bags containing lupin. In all experimental treatments, the lupin seeds always remained submerged.

While the experiment was carried out, the labour (h), electrical energy $(\mathrm{kWh})$, as well as water $(\mathrm{kg})$ and seed weight $(\mathrm{kg})$ were monitored. An ES 200L scale, Ohaus Corporation, NJ, U.S.A. was used for all weight measurements. During the experimental part, seed samples were taken and their alkaloid content was measured by titration as described earlier (Carvajal-Larenas et al., 2013). All experiments were terminated when the alkaloid content was reduced to the safe level (maximum $0.26 \%$ d.w.).

\section{Price}

The price for the debittered lupin was determined as follows. First the monthly profits were calculated for all treatments if they 
Table 1

Average values \pm standard deviation for Liking (scale 1-9), price and purchase intent (scale 1-4) for lupin debittered by 12 aqueous treatments.

\begin{tabular}{|c|c|c|c|c|}
\hline Treatment & Code & Liking ${ }^{\mathrm{a}, \mathrm{b}}$ & Price $(\$ / \mathrm{kg})$ & Purchase intent ${ }^{b}$ \\
\hline 6 water changes/day, $0 \mathrm{~h}$ of hydro-agitation/day & W6H0 & $6.4 \pm 1.9^{\mathrm{a}}$ & 1.64 & $2.0 \pm 1.0$ \\
\hline 2 water changes/day, $0 \mathrm{~h}$ of hydro-agitation/day & W2HO & $6.0 \pm 1.5^{\mathrm{a}, \mathrm{b}}$ & 1.62 & $2.1 \pm 1.0$ \\
\hline 3 water changes/day, $0 \mathrm{~h}$ of hydro-agitation/day & W3H0 & $6.1 \pm 2.0^{\mathrm{a}, \mathrm{b}}$ & 1.52 & $2.1 \pm 1.1$ \\
\hline 2 water changes/day, $22 \mathrm{~h}$ of hydro-agitation/day & W2H22 & $5.9 \pm 1.9^{\mathrm{a}, \mathrm{b}}$ & 2.17 & $2.8 \pm 1.1$ \\
\hline 9 water changes/day, $0 \mathrm{~h}$ of hydro-agitation/day & W9H0 & $5.6 \pm 1.6^{\mathrm{a}, \mathrm{b}}$ & 1.72 & $2.5 \pm 1.1$ \\
\hline 9 water changes/day, $22 \mathrm{~h}$ of hydro-agitation/day & W9H22 & $5.6 \pm 1.8^{\mathrm{a}, \mathrm{b}}$ & 2.16 & $2.6 \pm 1.2$ \\
\hline 6 water changes/day, $11 \mathrm{~h}$ of hydro-agitation/day & W6H1 & $5.4 \pm 1.8^{\mathrm{a}, \mathrm{b}}$ & 1.92 & $2.6 \pm 1.1$ \\
\hline 9 water changes/day, $11 \mathrm{~h}$ of hydro-agitation/day & W9H11 & $5.6 \pm 1.8^{\mathrm{a}, \mathrm{b}}$ & 1.83 & $2.6 \pm 1.1$ \\
\hline 2 water changes/day, $11 \mathrm{~h}$ of hydro-agitation/day & W2H11 & $5.6 \pm 2.2^{\mathrm{a}, \mathrm{b}}$ & 1.97 & $2.5 \pm 1.2$ \\
\hline 3 water changes/day, $11 \mathrm{~h}$ of hydro-agitation/day & W3H11 & $5.6 \pm 1.8^{\mathrm{a}, \mathrm{b}}$ & 1.82 & $2.7 \pm 1.0$ \\
\hline 3 water changes/day, $22 \mathrm{~h}$ of hydro-agitation/day & W3H22 & $5.3 \pm 2.0^{\mathrm{b}}$ & 2.13 & $3.0 \pm 1.1$ \\
\hline 6 water changes/day, $22 \mathrm{~h}$ of hydro-agitation/day & W6H $22^{\mathrm{b}}$ & $4.7 \pm 1.9^{b}$ & 1.92 & $2.7 \pm 1.0$ \\
\hline
\end{tabular}

a Tukey's test. Treatments with different letters are significantly different.

b Ninety-nine consumers judged 4 (out of 12 ) samples each. Thus, each sample was evaluated 33 times.

would be sold at the current price of debittered lupin in the market, minus the production costs, using the following equation:

$\mathrm{MP}=(\mathrm{PP} *(1-f)-(\mathrm{Ma}+E+L+D)) * W *(30 / t)$

where, $\mathrm{MP}=$ Monthly profit $(\$ /$ month $)$; $\mathrm{PP}=$ Product Price in the market ( $\$ 1.52 / \mathrm{kg}$ product); $f=$ fraction of product price that is retained by supermarket (supermarket profits) (0.20); Ma = Materials cost ( $\$ / \mathrm{kg}$ product); $E=$ Energy cost ( $\$ / \mathrm{kg}$ product); $L=$ Labour cost $(\$ / \mathrm{kg}$ product); $D=$ Depreciation ( $\$ / \mathrm{kg}$ product); $W=$ Product obtained $(\mathrm{kg} / \mathrm{batch}) ; 30=$ average month (days); $t=$ time to complete a production batch (days).

Components of production costs (i.e. Ma, $E$ and $L$ ) were determined based on the amount of resource used per $\mathrm{kg}$ of product and multiplied by the unitary cost (namely, $\$ 1.89 / \mathrm{kg}$ raw lupin; $\$$ $0.0005 / \mathrm{l}$ water; $0.14 \$ / \mathrm{kWh}$; $0.14 \$ / \mathrm{kg}$ petroleum gas; $\$ 1.99 / \mathrm{h}-\mathrm{m}$ (hour-man). Depreciation $(D)$ was calculated as follows. First, the investments for the facilities (tank, pump, pipes, accessories and instruments) were summed and this value was divided by the number of days the facilities could be used (1825 days or 5 years of life time). The resulting value ( $\$ 0.94 /$ day) was multiplied by the time $(\mathrm{t})$ to complete a production batch (days). Finally, all costs (Ma, $E, L$ and $D$ ) were summed.

Then, the process with the highest monthly profits was selected and used as reference for all other processes to calculate the price for that particular treatment at the same profit margin, where Eq. (1) was reworked into:

$P_{i}=\frac{\left(\left(\frac{\mathrm{MP}_{h} * t_{i}}{W_{i} * 30}\right)+\mathrm{Ma}_{i}+E_{i}+L_{i}+D_{i}\right)}{(1-f)}$

where, $\mathrm{MP}_{h}=$ Highest monthly profit $\left(\$ /\right.$ month); $P_{i}=$ Price that a consumer would have to pay ( $\$ / \mathrm{kg}$ product); $i=$ investigated process $(i=1, \ldots, 12)$.

\section{Liking}

Lupin seeds that were debittered according to the twelve conditions mentioned before, were boiled for $10 \mathrm{~min}$ to ensure bacteriological safety for consumption (Villacrés et al., 2000), packed in polyethylene bags, cooled in a water bath at $16{ }^{\circ} \mathrm{C}$ and kept frozen conditions $\left(-16^{\circ} \mathrm{C}\right)$ until all batches had been produced. Then, all samples were defrosted in a water bath $\left(60^{\circ} \mathrm{C}\right)$ until the samples reached $4{ }^{\circ} \mathrm{C}$. Finally all samples were kept 1 day under refrigeration conditions $\left(4^{\circ} \mathrm{C}\right)$ to equilibrate the temperature.

Liking was assessed using a sample of the population. Requirements for respondents were that they should eat lupin at least once per month, be healthy and between 18 and 65 years old.
Consumers were instructed how to complete the questionnaire and asked not to eat anything for at least $1 \mathrm{~h}$ prior to the test.

The number of consumers, the number of samples that each consumer tried, the order of presentation of samples and the code assigned to each sample were obtained throughout a Design Generator Form, Incomplete Block design that the program Qi statisticDesign Express version 1.6 offers (http://www.qistatistics.co.uk/). The obtained design did not have any carry over effect, presented a statistical efficiency $>80 \%$ (same potency that others designs but using less samples) and was balanced (all samples were evaluated for the same number of judges).

Ninety-nine volunteer consumers ( 50 men, 49 women, 18 to 68 -year old, students, administrators and faculty of the Universidad San Francisco de Quito, Ecuador) judged 4 samples each from left to right. Thus, each sample was evaluated 33 times. The consumers were physically separated and could not communicate with each other. After tasting each sample consumers had to register the degree of liking of the sample, take two sips of water, and wait for at least $10 \mathrm{~s}$ before continuing with the next sample. The form used was a 9-point hedonic scale presented vertically. The highest point corresponded to "like extremely" and scored 9 points; "like very much", 8 points; "like moderately", 7 points; "like slightly", 6 points; "neither like nor dislike", 5 points; "dislike slightly, 4 points; "dislike moderately", 3 points; "dislike very much", 2 points and "dislike extremely", 1 point.

\section{Purchase intent}

Immediately after finishing the evaluation of the liking and when consumers were still in possession of their answers, each respondent received written and verbal information about the price that the 4-previously tried samples would have in the market. Then, each consumer ranked his P.I. based on both his liking evaluation and the communicated price. The most preferred sample scored 1 and the least preferred 4 .

\section{Willingness to pay}

Willingness to pay was not obtained experimentally but was inferred from studying the effect of price and liking on purchase intent combined with the economic concept of equity theory (Bolton \& Lemon, 1999; Homburg et al., 2005). In order to do this, purchase intent was plotted first, then the different levels of purchase intent were located. Next, while keeping the same level of P.I. (as a marker of fair exchange), the two extreme combinations of liking and price were quantified by reading the values in the plotted area. 


\section{Data analysis}

The twelve debittering treatments were evaluated as follows. A parametric two-way ANOVA test was used to assess differences in degree of liking. In addition, Tukey's test was used to assess multiple comparisons between treatments. Both evaluations were done using the program Minitab version16 (www.minitab.com/en-us/). One sample $t$ test was used to evaluate differences in price of all treatments; for the price of the treatment currently applied, W3H0 was used. For this purpose, the software package GRAPH PAD INSTAT T.M. V2.01., GraphPad Software Inc., San Diego, California, U.S.A. was used. A non-parametric Kruskal-Wallis test was used to quantify differences in degree of P.I. The computer program Minitab version 16 was also used to that end. In addition, the two-factor ANOVA test was used to measure the effect of each

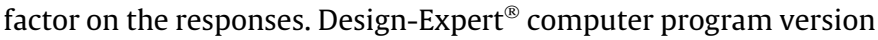
8.0, Stat-Ease, Inc., Minneapolis, Minnesota, U.S.A. was used. This program was also used to model the effect of processing conditions on degree of liking, price and P.I.

Finally, to select the most desirable combination of goals (i.e. maximization of liking, minimization of price and with the highest P.I.) a desirability function was used, which is an objective function that combines all factors' and responses' goals into one equation. There, the particular influence of a goal can be altered by adjusting the weight or importance. The numerical optimization finds a point that derives (maximizes) the desirability function and scores between one (on the goal) to zero (outside of limits). In our case, each treatment was scored according to those goals by using the computer program Design-Expert ${ }^{\circledR}$, version 8.0. All variables (i.e. liking, price) had the same weight and importance. Treatments distant from the most desirable combination got a low score, and those closer got a higher score. Therefore, the highest score was for the combination (treatment) closest to the most desirable combination.

\section{Results}

\section{Effect of processing conditions on liking of debittered lupin}

The effect of number of changes of water (code: W) and hours of agitation (code: $\mathrm{H}$ ) on liking of debittered lupin is presented in Tables 1 and 2. The liking of all samples was between 6.4 (W6H0) and 4.7 (W6H22). The aqueous process applied currently on a commercial scale (W3H0) scored 6.1. The two-way ANOVA test indicates significant differences between treatments and between judges (Table 2). Tukey's multiple comparison test shows three clusters: treatment W6H0 as the treatment most liked (6.4), treatment $\mathrm{W} 6 \mathrm{H} 22(4.7)$ as the least liked and the other treatments in between (range 6.1-5.3) (Table 1). Evidently the treatment without agitation was the most liked.

The effect of changes of water and agitation time on liking was also analyzed through a response surface methodology (RSM). Several models (linear, 2FI, quadratic and cubic) were analyzed (data not included). However, the linear model proved to be the best (Table 2, Fig. 1A and B) to reflect the liking trend. Fig. 1A shows an inverse and additive effect on liking of either agitation time or

Table 2

Two-way ANOVA for liking of lupin debittered by 12 aqueous treatments (incomplete block design).

\begin{tabular}{lrrllll}
\hline Source & \multicolumn{1}{c}{ DF } & \multicolumn{1}{c}{ SS } & SS adjust & MS adjust & $F$ & $P$ \\
\hline Treatment & 11 & 64.694 & 73.651 & 6.696 & 2.58 & 0.004 \\
Judge & 98 & 607.810 & 607.810 & 6.202 & 2.39 & 0.000 \\
Error & 286 & 741.099 & 741.099 & 2.591 & & \\
Total & 395 & 1413.604 & & & & \\
\hline
\end{tabular}
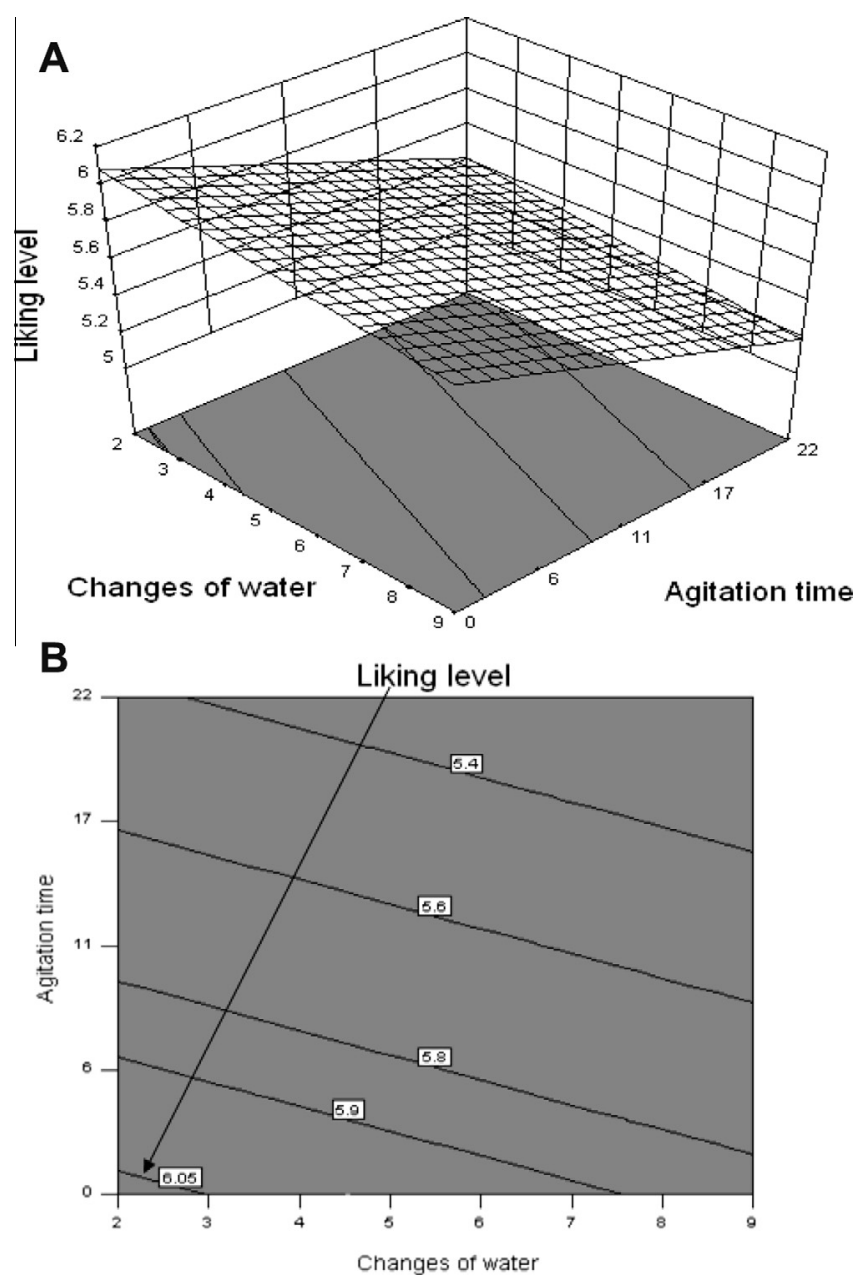

Fig. 1. Effect of changes of water and agitation time on liking of lupin debittered by 12 aqueous treatments. Representation of this relationship on 3D (A) and 2D (B).

Table 3

Two-factor ANOVA for the Response Surface Linear Model for liking of lupin debittered by 12 aqueous treatments.

\begin{tabular}{lrrlll}
\hline Source & DF & SS & MS & \multicolumn{1}{l}{ F } & $P$ \\
\hline Model & 2 & 31.90 & 15.95 & 4.54 & 0.0113 significant \\
Factor A-Changes of water & 1 & 3.23 & 3.23 & 0.92 & 0.3381 \\
Factor B-Agitation & 1 & 28.67 & 28.67 & 8.15 & 0.0045 \\
Residual & 393 & 1381.70 & 3.52 & & \\
Total & 395 & 1413.60 & & & \\
\hline
\end{tabular}

number of water changes. Nevertheless, the effect of agitation on liking is higher than the effect of changes of water. This is confirmed by the two-factor ANOVA test (Table 3). The higher liking values were estimated when there was practically no agitation (Fig. 1B).

\section{Effect of processing conditions on expected price of debittered lupine}

The combined effect of processing conditions on price is presented in Table 1, and Fig. 2A and B. The price varied between $1.52 \$ / \mathrm{kg}(\mathrm{W} 3 \mathrm{H} 0)$ and $2.17 \$ / \mathrm{kg}$ (W2H22) (Table 1). One sample $t$ test showed an extremely significant difference $(p=0.0002$, two tailed) between the expected price of products obtained with treatments applied in this study and the price with the commercial treatment $(\$ 1.52 / \mathrm{kg})(\mathrm{W} 3 \mathrm{H} 0)$. Fig. 2A shows the direct effect of hours of agitation and changes of water on the price of the product. However, the effect of agitation was much larger than the effect of 


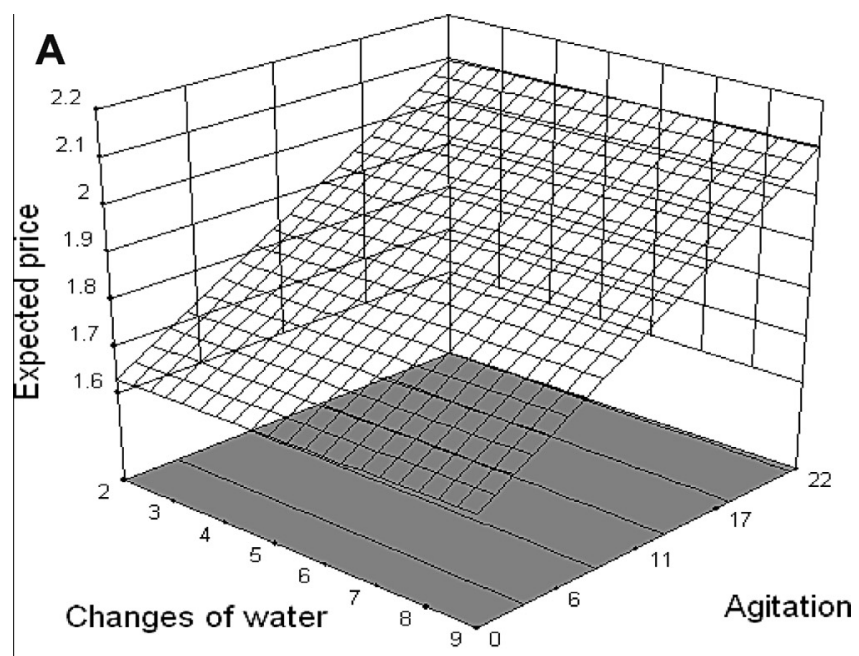

B

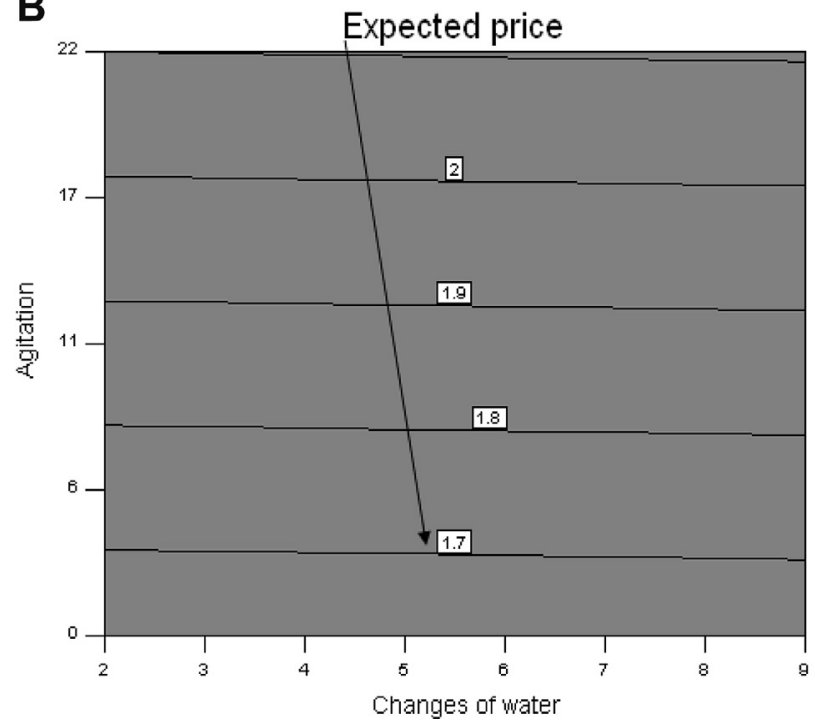

Fig. 2. Effect of changes of water and agitation time on price of lupin debittered by 12 aqueous treatments. Representation of this relationship on 3D (A) and 2D (B).

Table 4

Two-factor ANOVA for the Response Surface Linear Model for expected price of lupin debittered by 12 aqueous treatments.

\begin{tabular}{lrllll}
\hline Source & DF & SS & MS & $F$ & $P$ \\
\hline Model & 2 & 0.44 & 0.22 & 25.09 & 0.0002 significant \\
$\quad$ Factor A-Changes & 1 & $1.111 \mathrm{E}-004$ & $1.111 \mathrm{E}-004$ & 0.013 & 0.9130 \\
$\quad$ of water & & & & & \\
$\quad$ Factor B-Agitation & 1 & 0.44 & 0.44 & 50.17 & $<0.0001$ \\
Residual & 9 & 0.079 & $8.806 \mathrm{E}-003$ & & \\
Total & 11 & 0.52 & & & \\
\hline
\end{tabular}

changes of water. This is confirmed by the two-factor ANOVA test (Table 4). The effect of agitation on price is significant and the effect of water changes is not. Lower prices were obtained when there was no agitation (Table 1 and Fig. 2B).

Effect of liking and expected price on P.I. and W.T.P. and the optimum solution

The effect of liking and price on P.I. is presented in Tables 1 and 5. The P.I. varies between 2.0 (W6H0) and 3.0 (W3H22) (Table 1), with an extremely significant difference between treatments (Table 5). Note that the product that was obtained by W6HO had
Table 5

Kruskal-Wallis test for purchase intent of lupin debittered by 12 aqueous treatments.

\begin{tabular}{lllll}
\hline Treatment & $N$ & Median & Mean classification & $Z$ \\
\hline W3H0 & 33 & 2.000 & 161.0 & -1.97 \\
W6H11 & 33 & 3.000 & 203.0 & 0.24 \\
W2H22 & 33 & 3.000 & 224.0 & 1.34 \\
W9H11 & 33 & 3.000 & 209.0 & 0.55 \\
W6H22 & 33 & 3.000 & 221.0 & 1.18 \\
W2H0 & 33 & 2.000 & 155.0 & -2.28 \\
W9H22 & 33 & 3.000 & 203.0 & 0.24 \\
W9H0 & 33 & 3.000 & 197.0 & -0.08 \\
W3H22 & 33 & 3.000 & 251.0 & 2.75 \\
W6H0 & 33 & 2.000 & 146.0 & -2.75 \\
W2H11 & 33 & 2.000 & 197.0 & -0.08 \\
W3H11 & 33 & 3.000 & 215.0 & 0.86 \\
General & 396 & & 198.5 & \\
$H=26.18$ & FD 11 & $p=0.006$ & & \\
$H=26.18$ & FD $=11$ & $p=0.003$ & (adjusted) & \\
\hline
\end{tabular}

the highest score for liking, namely 6.4, and the third lowest price of $1.64 \$ / \mathrm{kg}$, after $1.52 \$ / \mathrm{kg}$ (W3H0) and $1.62 \$ / \mathrm{kg}$ (W2H0) (Table 1). The modeling of liking and price on P.I. was done by using different approaches of RSM (namely linear, 2FI, quadratic, cubic) (data not shown). The linear equation proved to be the best (Table 6). The two-factor ANOVA test applied to this model indicated a significant effect of both factors, namely liking and price on P.I. (Table 6).

\section{Discussion}

\section{Effect of processing conditions on liking of debittered lupin}

Because there is no information available about the effect of processing conditions on liking and price of debittered lupin or on the effect of liking and price on P.I., we compare and discuss our findings with available literature on other products. Thus, the coefficients of variation in our study (standard deviation/ mean) ${ }^{*} 100$ (i.e. $(1.9 / 6.4) * 100=29.7 \%$ or $\left.(1.9 / 4.7) * 100=40.4 \%\right)$ (Table 1), were similar or lower than in another study (Homburg et al., 2005) that measured consumer satisfaction in a restaurant (i.e. $(1.6 / 3.4)^{*} 100=47.1 \%$ or $(2.3 / 5.9)=39.0 \%$ ). In addition, Ghasemlou et al. (2013) found for common bean (Phaseolus vulgaris) that by changing processing conditions (cooking time, cooking temperature, concentration of added $\mathrm{NaCl}$ and $\mathrm{CaCl}_{2}$ the consumers' overall acceptability, on a 9 points hedonic scale, varied from about 2.5/9 to about 8/9. Consumers liked most samples with an average firmness between 12.5 and $22.5 \mathrm{~N}$, and they disliked most samples with high value of firmness (i.e. $52.9 \mathrm{~N}$ ). Zhang et al. (2010) reported that winter Anjou pears under different conditions of ripening (0, 2, 4 and 6 days of ethylene treatments) were evaluated by between 100 and 120 consumers on a 9 points hedonic scale. Results showed that the overall desirability varied between $4.3 / 9$ and $7.5 / 9$. In this study consumers liked most products obtained with 6-day ethylene treatment, and disliked most products obtained without ethylene treatment. Holmquist et al. (2011) evaluated the overall preference of three chardonnay wines obtained from three different treatments by 66 consumers on a 9point hedonic scale. The winning treatment (not aged in oak barrels) obtained 6.5/9. The other treatments scored 5.6/9 and 6.0/9 for $100 \%$ oak-aged and $70 \%$ oak-aged, respectively.

Response surface methodology for modeling the influence of processing conditions on different sensory attributes was also used by Ghasemlou et al. (2013). The authors measured the combined effect of thirty different processing conditions on two rheological parameters of cooked P. vulgaris (force and deformation) indicating that the RSM methodology is suitable for reflecting differences 
Table 6

Two-factor ANOVA for the Response Surface Linear Model for purchase intent of lupin debittered by 12 aqueous treatments.

\begin{tabular}{lrllll}
\hline Source & DF & SS & MS & \multicolumn{1}{l}{$F$} & $P$ \\
\hline Model & 2 & 136.08 & 68.04 & 74.50 & $<0.0001$ significant \\
Factor A-Liking level & 1 & 112.76 & 112.76 & 123.47 & $<0.0001$ \\
Factor B-Expected price & 1 & 12.77 & 12.77 & 13.98 & 0.0002 \\
Residual & 393 & 358.92 & 0.91 & & \\
Total & 395 & 495 & & & \\
\hline
\end{tabular}

between a number of processing conditions. The authors did not model that relationship although the sensorial evaluation of all samples was carried out.

\section{Effect of processing conditions on expected price of debittered lupine}

The effect of processing conditions on product cost (and price) found in this study is confirmed by Ghasemlou et al. (2013), Zhang et al. (2010) and Holmquist et al. (2011). For example, Zhang et al. (2010) estimated that the costs for pear ripening were associated to the size of operations, increased use of facilities (machinery), energy and ethylene. These authors found an increase of about $\$ 0.002$ per kilogram of pears for every 2 days of ethylene treatment. Unfortunately, in this study the labour cost was not taken into account. No published mathematic models were found that link processing conditions to product cost or price to compare our findings with. However, as Zhang et al. (2010) pointed out, costs are highly variable and depend on the size of the operations. Therefore, different mathematic models describing process-cost relations can be expected. In this research, a first order regression equation describing the effect of agitation and changes of water on price proved to be adequate.

Effect of liking and expected price on P.I. and W.T.P. and the optimum solution

In literature we did not find models that reflect the effect of price and liking on P.I. to compare our findings with, because most of the time such studies only analyze two variables. Nevertheless, we compared our data with available research. Thus, in our model (Fig. 3A and B) respondents scored a P.I. of 2.0, either when the product scored a liking of about 6.2 and would be sold at $1.50 \$ /$ $\mathrm{kg}$, or when it would be sold at about $1.8 \$ / \mathrm{kg}$ when the liking score was 7.0 (Fig. 3B). This indicates that when the price increases, the liking should be increased too in order to keep the same P.I. (Fig. 3B). From this information it can be inferred that respondents would be willing to pay $0.3 \$ / \mathrm{kg}$ more for a product they like better. These findings are in line with Stefani et al. (2006), Zhang et al. (2010), Homburg et al. (2005) and Rosas-Nexticapa, Angulo, and O'Mahony (2005), who also reported a positive correlation
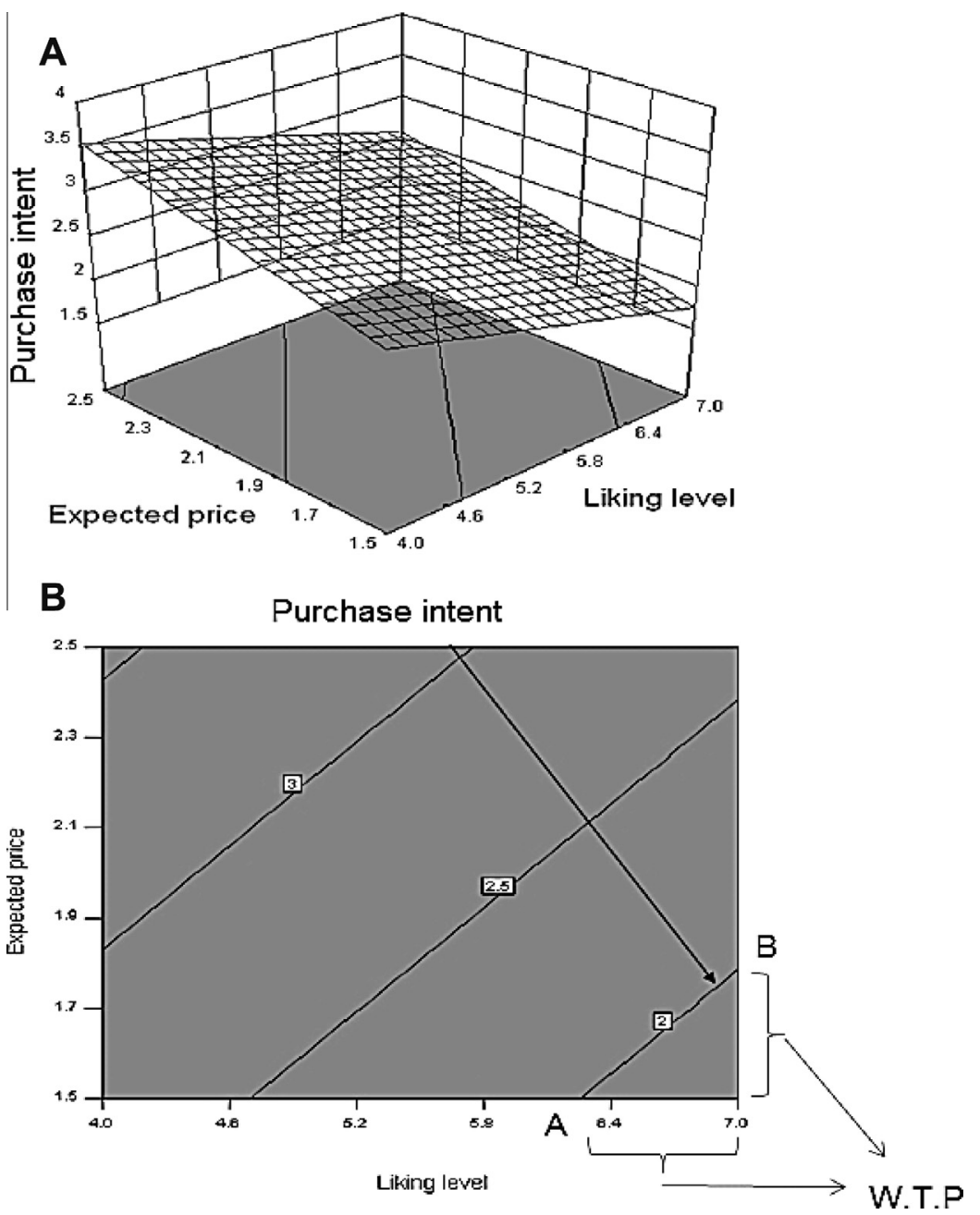

Fig. 3. Effect of price and liking on purchase intent of lupin debittered by 12 aqueous treatments. Representation of this relationship on $3 \mathrm{D}$ (A) and $2 \mathrm{D}$ (B). 

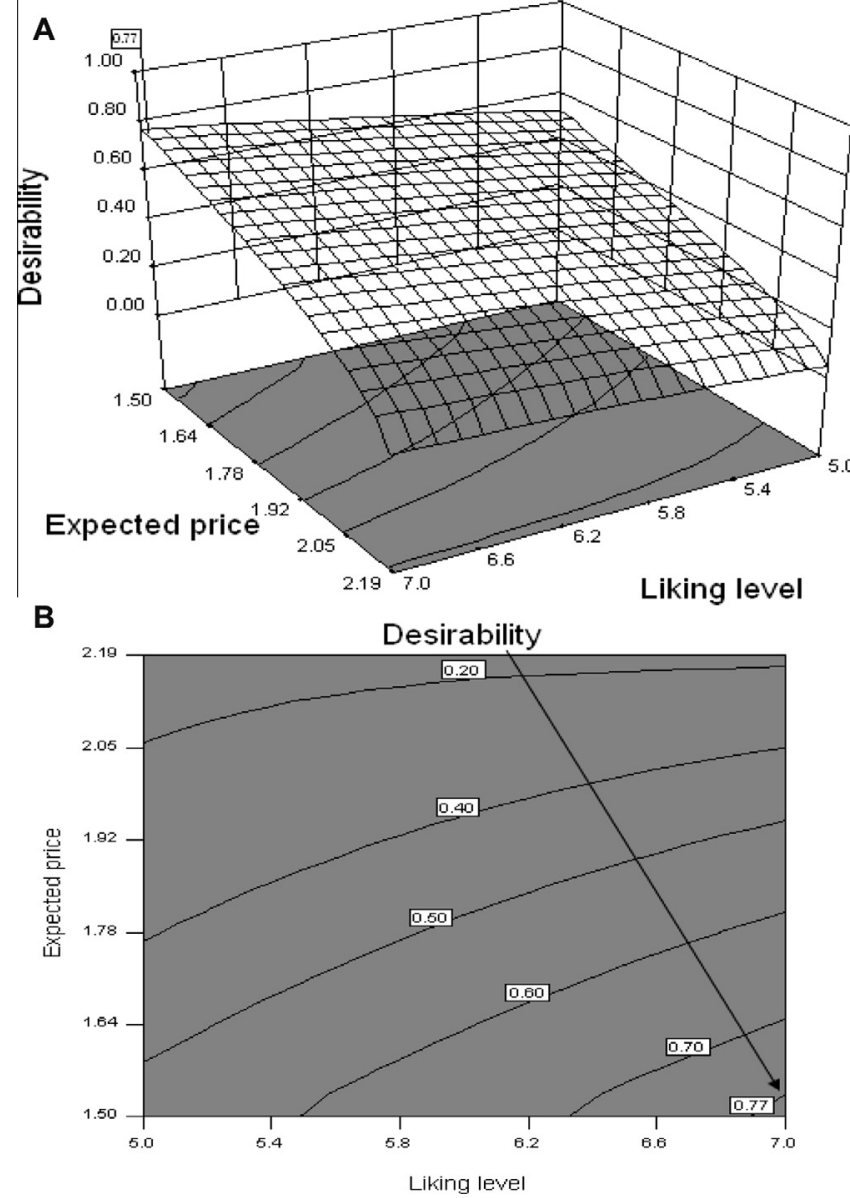

Fig. 4. Purchase intent (P.I.) as related to liking level and expected price to determine the most desirable combination ("desirability"). Representation of this relationship in 3D (A) and 2D (B). Treatments distant from the most desirable combination (i.e. maximization of liking, minimization of price and with the best possible P.I.) received a low score $(0.20$ or 0.40$)$, and those closer got a higher score ( 0.60 or 0.70$)$. Therefore, the highest score $(0.77)$ was for the combination (treatment) closest to the most desirable combination.

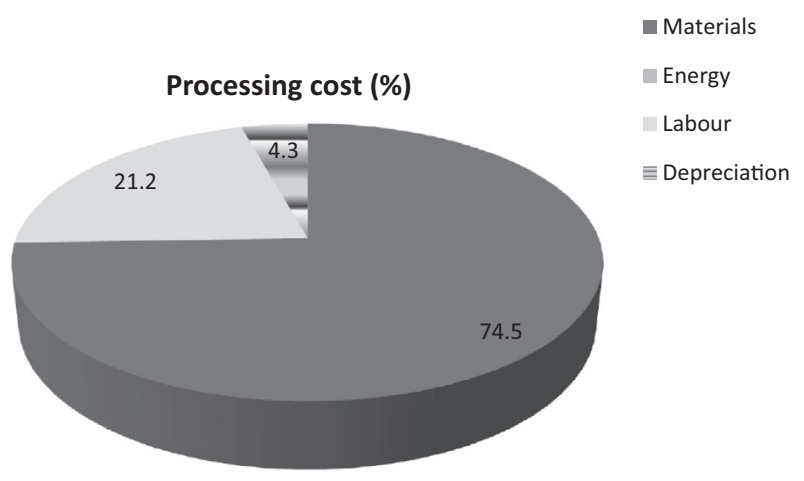

Fig. 5. Processing costs (\%) for treatment W3H0. Energy does not show since it is $0 \%$.

between products that were liked better and a higher price for a specific product.

For example, Zhang et al. (2010) found that compared to the average market price of $0.68 \$ / \mathrm{kg}$, consumers were willing to pay a premium of $0.11 \$ / \mathrm{kg}$ for pears processed under specific conditions of ripening (six-day ethylene treatment). Moreover, in the study performed by Holmquist et al. (2011), consumers were willing to pay $\$ 0.67$ more for a full bottle of un-oaked chardonnay wine compared with a full oaked bottle of chardonnay because they like the first more.

As for the liking - willingness to pay models, and despite the fact that in our study that relationship was obtained by inference, it is possible to observe that this would have a linear trend (Fig. 3B). When comparing our findings with literature, we found contradictory information. For example, Stefani et al. (2006) studied the effect of region of origin of food products on willingness to pay and reported a linear relationship. In addition, Anderson (1996) studied the relation between consumer satisfaction and price tolerance (the maximum price that consumers are willing to pay before switching) and reported to assume a linear link between those variables. Homburg et al. (2005) also studied the effect of consumer satisfaction and willingness to pay. In that study, consumer satisfaction was measured as a function of three key attributes, namely quality of food, ambience, and service. These authors studied two models, namely linear and cubic models. The linear model found had a $p$ value of 0.000 for both parameters $b_{0}$ and $b_{1}$ and the cubic model also had a $p$ value of 0.000 for the parameters $b_{0}, b_{1}$ and $b_{3}$. However, the $b_{2}$ parameter was not significant (0.785). The authors chose the cubic model because their findings were analyzed under two information criteria, which were slightly lower, in favor of the cubic model; Akaike's information criterion (AIC) gave 4492 for cubic and 4527 for linear and the Bayesian information criterion (BIC) 4506 for cubic and 4537 for linear. The cubic function found, described as S-inverse shape, was concave for low satisfaction levels, convex for high satisfaction levels, and relatively flat for medium satisfaction levels.

This apparent difference between the data of Homburg et al. (2005) and the present study could be explained as follows. First, the liking scores for our samples were between $6.4 / 9$ (i.e. close to "like slightly") and 4.7/9 (i.e. close to "neither like nor dislike"), so they can be considered of "medium satisfaction level", corresponding to the model found by Homburg et al. (2005) for the relatively flat segment. None of our lupin samples could be considered to result in high or low satisfaction. Therefore, in our model the concave and convex parts would be absent. Second, even though the cubic model has AIC and BIC criterions in its favor, the difference with the linear model is slight. In addition, both models have significant terms (except for $b_{2}$ in cubic model). Finally, not all products might generate a similar response from consumers. Homburg et al. (2005) studied the effect of 8 written scenarios that were set in a restaurant context and were evaluated with 80 students of a German University, whereas we studied the responses of 99 consumers (students, lecturers and administrators of an Ecuadorian University) after debittered lupin using 12 different aqueous treatments. Fig. 4A presents the optimization or highest desirability (maximization of liking, minimization of price and with the best possible P.I.). The optimal solution (desirability $\approx 0.77$ ) would be reached with a liking of about $6.9 / 9$ and a price of $1.50 \$ / \mathrm{kg}$ (Fig. 4B).

Treatment W3H0, the current way in which processors in Ecuador debitter lupin, is closest to the optimal combination of liking, price and P.I. (Table 1 and Fig. 5). Perhaps the reason for this is because consumers preferred what they are acquainted to, for many years, combined with the lowest price (and processing costs) of the product obtained with this treatment since the P.I. is the resultant consequence of both variables (liking and price).

\section{Conclusions}

Many studies suggest the importance of processing cost and/or price of product in consumer decisions (Bi, House, Gao, \& Gmitter, 
2011; Frewer et al., 1997; Homburg et al., 2005; Liu et al., 2006; Rosas-Nexticapa et al., 2005; Zhang et al., 2010). However, most of the published studies did not actually consider that aspect. In our research we developed an approach that integrates technology, cost, and consumer decisions into an optimization model. In the present case of lupin debittering it was found that despite the fact that hydro-agitation reduced the processing time and the use of labour, the net effect of increasing processing (more agitation and water changes) increased the final cost and decreased the liking by consumers.

The respondents in this study did not choose between price or liking; they went for both. However, people could be willing to pay more if they perceived a benefit from the process used and/ or the obtained product. For example, consumers could be willing to spend about $0.3 \$ / \mathrm{kg}$ more for a product for which the liking would increase from 6.2 to 7 .

The best product selected by respondents corresponded to that obtained with treatment W3HO because this had the lowest price and was one of the most liked. However, the obtained optimum was valid within the study conditions only and could change in other scenarios. For example, the price of products could change as a consequence of varying the batch size (economy of scales). On the other hand, the liking of products could also vary. For example, by adding common salt or calcium chloride the firmness and taste of the lupin could change. Moreover, the addition of common salt or calcium chloride could affect the processing time and therefore the processing costs. Therefore, the optimal solution should be considered as a dynamic output that changes in relation to variations between and within factors.

The response surface methodology proved to be a useful tool to compare and model the effect of several processing conditions on liking, cost and P.I. Therefore, it is recommended to compare the response surface methodology with other approaches such as the logit model, double-bounded model, and linear and non-linear programming to get insights for optimization purposes.

The approach used in this study can also be applied to other products to estimate relationships between processing conditions, liking, price and purchase intention. The methodology used in this research to estimate willingness to pay is new and it could be used to estimate the monetary relation between value perceived and real processing cost.

\section{Acknowledgments}

This research was conducted in the context of the TELFUN project, supported by the INREF fund (Wageningen University, The Netherlands) and the Universidad San Francisco de Quito, Ecuador. The authors also want to thank the two anonymous reviewers for their useful comments.

\section{References}

Agosin, E., Diaz, D., Aravena, R., \& Yañez, E. (1989). Chemical and nutritional characterization of lupine tempeh. Journal of Food Science, 54(1), 102-104. 107.

Aguilera, J. M., \& Trier, A. (1978). The revival of the lupin. Journal of Food Technology, 70-76.

Aguilera, J. M., Gerngross, M. F., \& Lusas, E. W. (1983). Aqueous processing of lupin seed. Journal of Food Technology, 18, 327-333.

Anderson, E. W. (1996). Customer satisfaction and price tolerance. Marketing Letters, 7(3), 265-274

Australia New Zealand Food Authority. (2001). Lupin alkaloids in food. Technical report series No. 3. Australia: Australia New Zealand Food Authority.

Bi, X., House, L., Gao, Z., \& Gmitter, F. (2011). Sensory evaluation and experimental auctions: Measuring willingness to pay for specific sensory attributes. American Journal of Agricultural Economics, 94(2), 562-568.

Bolton, R. N., \& Lemon, K. N. (1999). A dynamic model of customeŕs usage of services: Usage as an antecedent and consequence of satisfaction. Journal of Marketing Research, 36(May), 171-186.

Caicedo, C., Peralta, E., Villacrés, E., \& Rivera, M. (2001). Poscosecha y mercado del chocho (Lupinus mutabilis Sweed) en Ecuador: INIAP-FUNDACIT. In E. Peralta
(Ed.), Chocho o lupino producción, fitonutrición, enfermedades y plagas, zonificación, mercado y poscosecha, agroindustria, guía del cultivo de chocho y costos de producción. Quito, Ecuador: Published as CD by INIAP-FUNDACIT.

Camacho, L., Sierra, C., Marcus, D., Guzmán, E., Campos, R., Von Bäer, D., et al. (1991). Nutritional quality of lupine (Lupinus albus cv. Multolupa) as affected by lactic acid fermentation. International Journal of Food Microbiology, 14, 277-286.

Carvajal-Larenas, F. E., van Boekel, M. A. J. S., Nout, M. J. R., Linnemann, A., \& Koziol, M. (2013). Modeling of the aqueous debittering process of Lupinus mutabilis Sweet. LWT Food Science and Technology, 53(2), 507-516.

Dagnia, S. G., Petterson, D. S., Bell, R. R., \& Flanagan, F. V. (1992). Germination alters the chemical-composition and protein quality of lupin seeds. Journal of the Science of Food and Agriculture, 60(4), 419-423.

FAO. (2012). FAO statistical databases. Rome: FAO/United Nations. Available online at <http://faostat.fao.org>.

Frewer, L. J., Howard, C., Hedderley, D., \& Shepherd, R. (1997). Consumer attitudes towards different food-processing technologies used in cheese production-The influence of consumer benefit. Food Quality and Preference, 8(4), 271-280.

Ghasemlou, M., Gharibzahedi, S. M. T., \& Emam-Djomeh, Z. (2013). Relating consumer preferences to textural attributes of cooked beans: Development of an industrial protocol and microstructural observations. LWT Food Science and Technology, 50(1), 88-98.

Gueguen, J., \& Cerletti, P. (1994). Proteins of some legume seeds: Soybean, pea, fababean and lupin. In B. J. F. Hudson (Ed.), New and developing sources of food proteins (pp. 145-193). London: Chapman and Hall.

Güémes-Vera, N., Peña-Bautista, R. J., Jiménez-Martínez, C., Dávila-Ortiz, G., \& Calderón-Domínguez, G. (2008). Effective detoxification and decoloration of Lupinus mutabilis seed derivatives, and effect of these derivatives on bread quality and acceptance. Journal of the Science of Food and Agriculture, 88, 1135-1143.

Holmquist, C., McCluskey, J., \& Ross, C. (2011). Consumer preferences and willingness to pay for oak attributes in Washington chardonnays. American Journal of Agricultural Economics, 94(2), 556-561.

Homburg, C., Koschate, N., \& Hoyer, W. D. (2005). Do satisfied customers really pay more? A study of the relationship between customer satisfaction and willingness to pay. Journal of Marketing, 69, 84-96.

Jiménez-Martínez, C., Hernández-Sánchez, H., \& Dávila-Ortíz, G. (2007). Disminution of quinolizidine alkaloids, oligosaccharides and phenolic compounds from two species of Lupinus and soybean seeds by the effect of Rhizopus oligosporus. Journal of the Science of Food and Agriculture, 87 1315-1322.

Jiménez-Martínez, C., Hernández-Sánchez, H., \& Dávila-Ortiz, G. (2003). Lupines: An alternative for debittering and utilization in foods. In G. Gutiérrez-López \& G. Barbosa-Cánovas (Eds.), Food science and food biotechnology (pp. 233-252). Boca Raton, FL, USA: CRC Press.

Liu, Y., Kow, F., Grewal, D., \& FitzGerald, D. (2006). Consumer purchase behaivor for oysters: An empirical study in some state capital of Australia. Internationa Journal of Consumer Studies, 30(1), 85-94.

Nossak, A. C., Vilegas, J. H. Y., Von Baer, D., \& Lanças, F. M. (2000). Supercritical fluid extraction and chromatographic analysisanalysis (HRGC-FID and HRGC-MS) of Lupinus spp. alkaloids. Journal of Brazilian Chemical Society, 11(5), 495-501.

Oliver, R. L., \& Swan, J. E. (1989a). Consumer perceptions of interpersonal equity and satisfaction in transactions: A field survey approach. Journal of Marketing, 53(April), 21-35.

Oliver, R. L., \& Swan, J. E. (1989b). Equity and disconfirmation perceptions as influences on merchant and product satisfaction. Journal of Consumer Research, 16(December), 372-383.

Ortiz, J. G. F., \& Mukherjee, K. D. (1982). Extraction of alkaloids and oil from bitter lupin seed. Journal of the American Oil Chemists Society, 59(5), 241-244.

Pate, J. S., Williams, W., \& Farrington, P. (1985). Lupin (Lupinus spp.). In R. J. Summerfield \& E. H. Roberts (Eds.), Grain legume crops (pp. 699-746). London: Collins Professional and Technical Books.

Rosas-Nexticapa, M., Angulo, O., \& O’Mahony, M. (2005). How well does the 9-point hedonic scale predict purchase frequency? Journal of Sensory Studies, 20, 313-331.

Rossetto, G. (1989). Lupin production and processing study. In Y. Birk, A. Dovrat, M. Waldman, \& C. Uzureau (Eds.), Lupin production and bioprocessing for feed, food and other by-products (pp. 70-75). Jerusalem, Israel: National Council for Research and Development.

Santana, F. C., \& Empis, J. (2001). Bacterial removal of quinolizidine alkaloids from Lupinus albus flours. European Food Research and Technology, 212(2), 217-224.

Santos, C. N., Ferreira, R. B., \& Teixeira, A. R. (1997). Seed proteins of Lupinus mutabilis. Journal of Agricultural and Food Chemistry, 45, 3821-3825.

Stefani, G., Romano, D., \& Cavicchi, A. (2006). Consumer expectations, liking and willingness to pay for specialty foods: Do sensory characteristics tell the whole story? Food Quality and Preference, 17, 53-62.

Torres-Tello, F., Nagata, A., \& Dreifuss-Spiegel, W. (1980). Métodos de eliminación de alcaloides en la semilla de Lupinus mutabilis Sweet [Methods of eliminating alkaloids from the seeds of Lupinus mutabilis Sweet]. Archivos Latinoamericanos de Nutrición, 30(2), 200-209.

Villacrés, E., Caicedo, C., \& Peralta, E. (2000). Diagnóstico del procesamiento artesanal, comercialización y consumo del chocho. In C. Caicedo \& E. Peralta (Eds.), Zonificación Potencial, Sistemas de Producción y Procesamiento Artesanal del Chocho (Lupinus mutabilis Sweed) en Ecuador: INIAP-FUNDACIT, Quito, Ecuador. In Peralta, E. (Ed.), Chocho o lupino producción, fitonutrición, enfermedades y plagas, zonificación, mercado y postcosecha, agroindustria, guía del cultivo de chocho y costos de producción. Quito, Ecuador: Published as CD by INIAP-FUNDACIT. 
Villacrés, E., Peralta, E., \& Alvarez, M. (2003). Chochos en su punto: INIAPFUNDACYT. In E. Peralta (Ed.), Chochos. Recetarios. Disfrute Cocinando con Chochos. Quito, Ecuador: Published as CD by INIAP-FUNDACYT.
Zhang, H., Gallardo, R. K., McCluskey, J. J., \& Kupferman, E. M. (2010). Consumers' willingness to pay for treatment-induced quality attributes in Anjou pears. Journal of Agricultural and Resource Economics, 35(1), 105-117. 